\title{
Correction to: Stage II and stage III periodontitis clinical burdens of HIV-1 undergoing antiretroviral therapy
}

\author{
Lucio Souza Gonçalves ${ }^{1}$. Dennis de Carvalho Ferreira ${ }^{1,2} \cdot$ Fabio Vidal $^{1} \cdot$ Rodrigo Carvalho Souza $^{1}$. \\ Cristiane Gonçalves $^{1} \cdot$ Priscila Pavan $^{1} \cdot$ Florence Carrouel $^{3} \cdot$ Denis Bourgeois $^{3} \cdot$ Gregory J. Seymour $^{4}$
}

Published online: 8 March 2022

○) Springer-Verlag GmbH Germany, part of Springer Nature 2022

\section{Correction to: Clinical Oral Investigations} https://doi.org/10.1007/s00784-021-04201-2

The original version of this article contained a mistake on Table 1.

The original article has been corrected.

Publisher's note Springer Nature remains neutral with regard to jurisdictional claims in published maps and institutional affiliations.

The original article can be found online at https://doi.org/10.1007/ s00784-021-04201-2.

Lucio Souza Gonçalves

luciogoncalves@yahoo.com.br

1 Postgraduation Programa in Dentistry, Estacio de Sa University, Avenida das Americas 700, Loja 218, Bloco 8 do Conjunto Comercial Citta - Barra da Tijuca, Rio de Janeiro, RJ 22640-100, Brazil

2 Universidade Veiga de Almeida, Rio de Janeiro, Brazil

3 University Claude Bernard Lyon 1, Laboratory "Health Systemic Process", EA4129, 69008 Lyon, France

4 School of Dentistry, The University of Queensland, Brisbane, Australia 